\title{
Islam og revolution
}

om mediering, virkeliggørelse og det umedieredes politik i den syriske opstand Af Thomas Vladimir Brønd

\begin{abstract}
This article deals with the ways in which Islam is put to use by the Syrian regime and its opposition in the Syrian Uprising. By applying anthropological theory about politics of immediation and political theory about ideologies to a specific case - namely bombings in Kafer Suseh in Damascus in December 2011 - the article illustrates how horrific images in the conflict are mediated as part of distinctive political projects. The article traces the work of anti-regime activists on the Internet and on TV as well as that of pro-regime representatives in order to understand the peculiar scapegoating processes that followed in the hours after the bombings. In effect, a certain dynamic of ideological mediation is proposed in which social, historical and political presuppositions are suppressed. Resurfacing the historical conditions of mediation gives a better understanding of how horrific events as the one in the case are mediated. On a fundamental level, the case and its analysis indicates how politics of immediation and ideology intertwine in battles over Islam and its future role in Syria.
\end{abstract}

\section{"Gud er stor!"}

\section{”Folket фnsker regimets fald!"}

Den 23. december 2011 sprang to kraftige bomber udenfor en bygning i Kafer Suseh-området i Damaskus, som angiveligt husede en eller flere af de syriske efterretningstjenester (mukhabarat). Ifølge det syriske statslige nyhedsbureau Sana kostede bomberne mindst 40 mennesker livet. Dette var det første bombeangreb i hovedstaden under opstanden, hvilket fik mange analytikere til at udpege hændelsen som "et vendepunkt i konflikten" ${ }^{1}$. Billeder af ødelagte bygninger, lemlæstede mennesker, ambulancer og udtalelser fra folk til stede nåede via det statslige, syriske TV til de internationale nyhedskanaler. Jeg selv zappede også forbi de hjemlige TV2 News og DR, som bragte nyheden. Kanalerne refererede til nyhedstelegrammer som meddelte, at Det Muslimske Broderskab havde taget ansvaret. Nogle timer senere blev denne meddelelse imidlertid dementeret den hjemmeside, som havde taget ansvaret for bomberne, viste sig at være falsk. Hvorfor disse 'falske' nyheder? Hvad var der rent faktisk sket? I døgnet efter bombesprængningen udspillede der sig et mærkværdigt spil på internettet, som fik konsekvenser for mediedækningen af bombehændelsen. En hændelse, som vi med inspiration fra Slavoj Zizeks (2008) brug af Alain 
Badiou skal anskue som en 'Begivenhed', og derfor skal forsøge at træffe en form for "afgørelse" for - med andre ord skal vi forsøge at indkredse og forstå hvad der foregik i forbindelse med bombningerne.

Ligesom i de $\varnothing$ vrige opstande i den arabiske verden spiller medier også i den syriske opstand en central rolle. Men meget tyder på, at den syriske opstand adskiller sig fra eksempelvis den egyptiske og tunesiske på et afgørende område - nemlig det religiøse. Det har tidligere været fremført at islam som slogan, tema og referencepunkt synes at være mere fremtrædende i den syriske opstand (Pierret 2011). Men det generelle billede på dette punkt er langt fra entydigt. Siden marts 2011 har mange af demonstrationerne udgået fra moskeerne, som (foruden kirkerne) er det eneste sted syrere kan forsamles lovligt. Moskeerne har derfor fungeret som samlingspunkt for et bredt spektrum af syrere - fra meget religiøse til sekulære og ikke-troende. Slogans ligner dem fra andre arabiske opstande om frihed (huriyya) og "folket ønsker regimets fald" (al-sha'b yurid isqat al-nizam) og andre ikkereligiøse og mere syriske varianter som "Ét, ét, ét! Det syriske folk er ét!" (Wahid, wahid, wahid al-sha'b al-suri wahid). Men disse suppleres hyppigt af mere religiøse slogans som "Gud er stor!" (Allah hu-akbar) og "Der er ingen anden Gud end Allah" (La-il-lah-il-Allah). Et mindretal af islamistiske demonstranter og militante grupper har også omformuleret det populære slogan "Folket $\emptyset$ nsker regimets fald" til "Folket ønsker Jihad-erklæring" (al-sha'b yurid 'ilan al-jihad) og "Ummaen (dvs. det islamiske samfund, red.) ønsker et islamisk kalifat" (al-ummah turid khilafa islamiyya). Billeder fra demonstrationer og kampe oploades på centrale websites som del af oppositionens kamp mod regimet (eksempelvis Sham News Networks sider på Facebook og YouTube). Regimet reagerer med brutal repression, afskærer kommunikationslinjer og udsender egne versioner af de voldelige kampe via websites (eksempelvis gennem det statslige nyhedsbureau Sanas hjemmeside og TV-station), hvor religiøse "ekstremister", salafister og terrorister udråbes som Syriens fjender. Udenfor Syrien genbruger satellitnyhedskanaler billeder fra både anti- og proregime websites i deres journalistiske behandling af samme begivenheder og videreformidler eller "medierer" demonstrationer, kampe og andre hændelser i Syrien ved brug af disse websites.

Der foregår således i den pågående syriske opstand et sammenspil mellem medier og islamreferencer som kræver yderligere refleksion. I denne artikel analyserer jeg bombningerne den 23 . december som eksempel for at forstå, hvordan islam indgår i regimets og oppositionens fors $\emptyset \mathrm{g}$ på at promovere distinkte ideologiske og politiske projekter. Inspireret af antropologisk teori om mediation og politisk teori om ideologi, vil jeg gennem dette case-studie illustrere, hvordan brugen 
af islam sandsynliggør, at der på et overordnet plan foregår en narrativ ${ }^{2}$ kamp om at definere Syriens fremtidige indretning og islams rolle heri.

Artiklen struktureres således; medieringsteorien præsenteres først som analytisk ramme. Derefter præsenteres casen, som analyseres og sættes i historisk perspektiv. Netop det historiske perspektiv er afgørende, og ofte fraværende i den gængse debat. Gennemgangen og det historiske perspektiv vil forklare hvordan et centralt narrativ er opstået; nemlig islam som trussel og regimet som sikkerhed mod denne trussel og dermed garant for fredelig sameksistens. Dette kan være med til at forklare hvorfor narrativet fastholdes gennem opstanden på regimets side, hvilket udefra kan virke absurd og har givet anledning til spekulationer om, hvorvidt Præsident Asad 'lever i en virkelighedsboble', osv. Slutteligt konkluderes og drages nogle perspektiver som kræver yderligere undersøgelser.

\section{Den ideologiske medierings terræn}

Billeder taget med smart-phones af demonstrationer, angreb på byer, kampe, lemlæstede mænd, kvinder og børn, ødelagte boligområder, mv. bruges meget aktivt af den aktivistiske opposition i og udenfor Syrien. Også regimet anvender egne reportager i det statslige tv til at mediere de samme hændelser. Islam som tema relaterer sig også til sådanne videoer, og for at kvalificere brugen af dem, er det først og fremmest vigtigt at trænge bag billedernes "umiddelbarhed". Nyere medieringsteori kan hjælpe i denne retning (Eisenlohr 2011, Engelke 2011, Hirschkind 2011, Meyer 2010, 2011, de Vries 2001). Her påpeges at det som medieres (budskab, billeder, lyd, osv.) træder i forgrunden på en så radikal måde, at mediers teknikalitet, materialitet og de sociale, politiske, historiske og institutionelle relationer, som er medvirkende til at producere det medierede, træder i baggrunden eller endda forsvinder. Hvordan kan det være? Og hvordan kan vi forstå denne 'baggrund' og dens relation til 'forgrunden', til den bombe-hændelse vi skal analysere i næste afsnit?

Ved "mediering" og "mediation" mener jeg ikke blot overførslen af oplysninger, billeder, lyd, stemninger, osv. fra et medie til et andet. I stedet er jeg inspireret af William Mazarellas tilgang til mediation, hvor begrebet betegner et ambivalent grundlag "for alt socialt liv": 
"Mediation involves the conceptual, technical, and linguistic practices by which the actual irreducible particularities of our experience are, apparently, reduced: in other words, rendered provisionally commensurable and thus recognizable and communicable in general terms. Needless to say, these processes are necessarily ideological. Social practices of mediation, often initially quite contested, are formalized as mechanisms, externalized as technologies, and naturalized as social orders. These are not simply objective, impersonal processes. Rather, mediation is (as Hegel knew) also the basis of self-consciousness and therefore of affect and desire. The gap between the concreteness of experience and materiality, on the one hand, and the conceptual generalization that social life requires, on the other, is the terrain on which we re-cognize ourselves in the paradoxical form of something outside ourselves.” (Mazarella 2006: 476, min fremhævning)

Det medierede er, med andre ord, en reduceringsproces som fremstår umiddelbart og ikke-medieret (Sontag 1977, 2003) eller virkeligt (Barthes 2004). Forskere som Mazarella opfatter denne fremstillingsproces som en ideologisk autoritets- og magtstrategi (Mazarella 2004, 2006), og dette perspektiv er afgørende for gennemgangen af vores case i næste afsnit. Der er dog endnu et vigtigt perspektiv at tilføje: Medieringsdynamikken har i en Israelsk-palæstinensisk sammenhæng og på paradoksal vis givet anledning til at tale om politics of immediation, hvor Lori A. Allen påviser hvordan palæstinensere, som er $\mathrm{i}$ et slags statsligt vakuum, anvender grusomme billeder af deres lidelse til at chokere - og dermed til at repræsentere sig selv overfor hinanden og det internationale samfund. Det karakteristiske ved palæstinensernes repræsentationer er ifølge Allen immediation som det ideal palæstinenserne tilstræber : "Immediation is the necessarily covert denial of mediation that occurs in the formal properties of institutions and social interactions that aspire to give access to an authentic experience and truth.” (Allen 2009: 162, min fremhævning)

Det er således denne artikels projekt at udforske hvordan islam bliver anvendt i den konkrete case ved at forbinde tre dele af analysen; først, på det generelle teoretiske plan, påpeger jeg medieringsmekanismen som ovenfor beskrevet. Dernæst analyseres bombningernes mediering, dvs. det "terræn", som Mazarella beskrev som "the gap between the concreteness of experience and materiality and the conceptual generalization that social life requires". Herved vil vi få indblik $\mathrm{i}$ hvilke sociale, politiske og historiske relationer, som trænges $\mathrm{i}$ baggrunden $\mathrm{i}$ den nuværende konflikt. Dette indblik er samtidig med til at tegne konturerne af de centrale, dominerende narrativer om bombningerne. Ved at analysere den konkrete case vil vi nærme os en forståelse af, hvordan syrere anvender grusomme begivenheder og billeder fra den syriske konflikt til at repræsentere sig 
selv og promovere distinkte politiske projekter. Dette vil hjælpe med en større forståelse for hvad der "virkeligt" skete den 23. december, og en bedre generel forståelse af opstanden.

\section{Bombningerne som Begivenhed}

"Når Alain Badiou lægger vægt på Sandheds-Begivenhedens uafgørelighed, er hans position radikalt forskellig fra den dekonstruktivistiske standardforestilling om uafgørelighed (Badiou 1989). For Badiou betyder uafgørelighed, at der ikke er nogen neutrale 'objektive' kriterier for en begivenhed: En Begivenhed fremstår kun for dem, der finder sig i dens kald eller, som Badiou formulerer det, en Begivenhed er selv-relaterende, den indbefatter sig selv - sin egen benævnelse blandt sine bestanddele. Det betyder ganske vist, at man er nødt til at træffe afgфrelse om en Begivenhed, men en sådan i sidste ende grundløs afgørelse er ikke 'uafgørelig' i normal forstand. Den minder derimod sælsomt meget om den hegelske dialektik, hvori en 'bevidsthedsfigur', som han allerede gør klart i indledningen til Åndens fanomenologi, ikke vurderes ud fra nogen ydre sandhedsstandard, men derimod på absolut immanent vis i kraft af spalten mellem den selv og dens eksemplificering/iscenesættelse. En Begivenhed er således ikke-Alt i præcis den lacanianske betydning af ordet: Den bliver aldrig helt verificeret, netop fordi den er uendelig/ubegrænset, dvs. fordi den ikke har nogen ydre grænse.” (Zizek 2008: 35, min fremhævning, hans kursivering)

Lad os se på det mærkværdige mediespil, som beskrevet i denne artikels indledning, der udspillede sig i døgnet efter bombeangrebene i Kafer Suseh. Vi skal vi anskue dette mediespil som en "eksemplificering/iscenesættelse" af bombe-"Begivenheden", og vi skal forsøge at træffe en "afgørelse" for denne Begivenhed:

Kort efter bombeangrebene udpeges al-Qaeda af Sana som ansvarlige for bomberne. Ifølge en blog skrevet af Thomas Pierret forekom meldingen så hurtigt efter bomberne, at det næsten virkede planlagt på forhånd ${ }^{3}$. Kort tid efter Sanas hurtige melding citerer flere internationale og arabiske medier en hjemmeside (ikhwan-sy.com) fra det Muslimske Broderskab for at tage ansvaret for bomberne. På hjemmesiden findes en udtalelse (bayan), som tager ansvaret både for bomberne og for en kidnapning den 21. december af fem iranske teknikere, som arbejdede på et kraftværk i Homs.

Dette får syriske netaktivister til at undersøge hjemmesiden nærmere. På siden whois.com ${ }^{4}$ finder man frem til, at hjemmesiden er registreret hos emailadressen "emile_k17@hotmail.com”. Denne email-adresse spores herefter til Facebook-siden, som tilhører en person ved navn Emile Qas Nasrallah. Aktivisterne bliver venner på Facebook med personen og finder ud af, at der er tale om 
en søn af Bassel Qas Nasrallah, som er rådgiver til Syriens officielle statsmufti, Ahmad Hassoun. Emile er kristen og angiveligt aktiv i det kristne miljø omkring Aleppo. Herefter udstilles Emile Qas Nasrallah $^{5}$ og den falske website på adskillige Facebook-sider og blogs ${ }^{6}$.

Imens "afsløringen" (som i dag har mange hundrede tusind "likes") af Emile Qas Nasrallah pågår i aktivistkredse, dementerer Det Muslimske Broderskab på deres officielle side, at have noget at gøre med bomberne og anklager i stedet regimet. De internationale og arabiske nyhedsbureauer bringer korrigerende nyheder om den falske hjemmeside, uden dog at nævne Emile Qas Nasrallah som formodet ophavsmand, og refererer til Broderskabets dementi.

Det er nærliggende at spørge om Qas Nasrallah er den rigtige ophavsmand? Og det er da også muligt at afgive falske oplysninger ved registrering af hjemmesider, dog kræver oprettelse en bekræftelse via en email-adresse. Og denne adresse blev netop sporet til Qas Nasrallahs Facebookprofil. Medmindre hans email-adresse er blevet hacket i det $\varnothing$ jeblik, som hjemmesideregistreringen skulle bekræftes, må man formode at Qas Nasrallah er ophavsmand.

Det afgørende er imidlertid ikke om han er den sande ophavsmand til den falske hjemmeside, ligesom det i denne sammenhæng heller ikke af afgørende, hvem der rent faktisk stod bag bomben den 23. december i Damaskus eller for den sags skyld kidnapningerne af de fem iranske teknikere i Homs den 21. december. Det centrale er den aktive narrative konfrontation; dvs. kampen om at udstille i bestemt politisk øjemed henholdsvis al-Qaeda, Broderskabet og regimet selv som syndebukke for hændelsen. Det afgørende, med andre ord, er medieringen af bombningen - og dermed de politiske, institutionelle, sociale processer som overskygges af selve budskabet.

Lad os derfor med inspiration fra citatet som indleder dette afsnit tænke bombningerne som en "Begivenhed". Selve iscenesættelsen eller medieringen af bombningerne er, som Zizek beskriver, "uendelig" - den er uden "ydre grænse". I tilfældet med bomben i Kafer Suseh kan vi blive ved med at finde flere medieomtaler, internetdiskussioner med kommentarer og likes, tekniske detaljer osv. Men lad os dog tilstræbe, som Zizek også fremhæver, en slags "afgørelse" i den "spalte" der opstår imellem Begivenhedens materialitet (her: selve bombningerne og dens ødelæggelser) og dens iscenesættelse eller mediering (her: som gennemgået ovenfor; fremstillingen af begivenheden på internet og TV påvirket af opposition og regime, samt konstruktionen af narrativer om 'modparten' som 'syndebuk'): 
Man siger, at "sejrherrerne skriver historien". Men konflikten i Syrien pågår endnu uden en sejrende part. Med det teoretiske udgangspunkt om mediering i baghovedet, kan vi omskrive det velkendte ordsprog i syrisk sammenhæng til "den, som medierer Begivenheder mest effektivt vinder kampen om at virkeliggøre dem”. En Begivenhed som bomberne i Kafer Suseh eller de mange bomber som er fulgt siden hen er selvsagt frygtelig virkelig for de mennesker, som er direkte involveret. Mennesker bliver dræbt og lemlæstede.

Men for resten af Syriens befolkning på 22 millioner mennesker og for verden udenfor, som kigger på via forskellige medier, er det afgørende, hvilken type informationer, samt deres 'æstetik' ${ }^{7}$, stemninger, osv. som akkompagnerer de chokerende billeder. Vi taler om de mekanismer hvormed vi undslipper Begivenhedens meningsløse materialitet og frygtelige kaos ved at "reducere den til symbolsk status, ved at udstyre den med betydning" (Zizek [1989]: 115). Vi taler altså med henvisning til Mazzarellas ord i foregående afsnit om det "terræn", hvor "konceptuelle generaliseringer" opstår som nødvendig del af det at være menneske - at genkende sig selv på paradoksal vis i noget som er "udenfor" os selv. Oplysningerne og æstetikken i dette terræn informerer og guider tilskuernes opmærksomhed i en bestemt retning og motiverer derved bestemte opfattelser af, hvad der rent faktisk er sket. Denne guidede opmærksomhed opstår på baggrund af en ideologisk mediering:

Aktivisternes undersøgelser er på sin vis spektakulære, nærmest som i et spion-drama, og bringer således "afsløringen" frem i lyset, alt imens den falske side fjernes - angiveligt fordi Qas Nasrallah er "ved at slette sine spor" ${ }^{\prime}$. Koblingen mellem Qas Nasrallah via sin far og statsmuftien Hassoun er oplagt og budskabet i narrativet derfor lysende klart: regimet står bag hjemmesiden og bombningerne! ${ }^{9}$ En række spørgsmål forsvinder imidlertid ud af billedet i denne medieringsproces ; nemlig om Qas Nasrallah handlede som sympatisør med regimet (og ikke efter ordre fra sin far eller andre) eller som en presset kristen, der frygter al-Qaeda, sunni-muslimsk indflydelse, religiøst motiveret vold osv. Ude af billedet er også det teknisk og indholdsmæssigt amatøragtige ved hele opsætningen af hjemmesiden, hvilket gjorde det relativt nemt at afsløre Qas Nasrallah. Og ude af billedet trænges ikke mindst regimets eget narrativ om, at al-Qaeda skulle stå bag bomberne.

Således trænger medieringen på aktivisternes side en række forhold i baggrunden. Funktionen af "afsløringen" giver umiddelbart indtryk af et klart motiv for Qas Nasrallah (støtte til regimet). Der er logik og gennemsigtighed i bevisførelsen. Det er derfor (ledes vi til at tro) virkelig "sandheden", som præsenteres. Og netop her finder vi den skjulte benægtelse af mediering, som Lori Allen

(C) Forfatteren og Tidsskrift for Islamforskning, ISSN 1901-9580, publiceret 1-03-2013 
beskrev i det tidligere afsnit. Og dermed finder vi "politics of immediation" i casen, som unægtelig er ideologisk. Ikke ideologisk som et parti eller et individ, der følger et særligt tilrettelagt ideologisk program eller bevæger sig inden for et bestemt ideologisk verdensbillede som eksempelvis kommunisme eller kapitalisme. Den skjulte benægtelse om mediering er $i$ sig selv en ideologisk manøvre, som indfinder sig i de handlinger, som aktivisterne foretager med henblik på at 'blotlægge' sandheden om bomben i Kafer Suseh og ligeså med regimets egen nyhedsdækning via det statslige nyhedsbureau Sana. Som Lori Allen skriver om palæstinenserne; "Potential political trajectories are obscured when feelings in the moment are the focus," (Allen 2009: 173). I den syriske sammenhæng kunne man argumentere for, at det ikke blot er de følelser, som unægtelig opstår i den umiddelbare reaktion på den frygtelige Begivenhed, som obstruerer eller forplumrer - i vores case er det også aktivisternes afslørings-æstetik, der samtidig skjuler en række potentielle politiske sammenhænge og baggrunde, som kunne være relevante for forgrundens forståelse. Selvom det ville være for omfattende at gennemgå pointen mere detaljeret, er det dog vigtigt at nævne, at selv samme mekanisme gør sig gældende i regimets egen mediering via det statslige TV; via chokerende billeder fra bombe-stedet, udtalelser fra sårede og medfølgende information om alQaeda som ansvarlig motiveres bestemte følelser og opfattelser i forgrunden, mens en række andre, "potentielle politiske baner" trænges i baggrunden.

Bomberne i Kafer Susa den 23. december 2011 og de gennemgåede medieringsmekanismer har også en længere historie, som ikke træder i forgrunden ved hændelsens umiddelbarhed, men som danner dens baggrund. Medieringens skjulte benægtelse og politik er langt fra tilfældig, men derimod historisk betinget. Denne historie eller genealogi rækker længere tilbage end blot marts 2011, hvor opstanden for alvor tog fart i Syrien. Genealogien kan være med til at kaste lys over, hvad der foregår i den "spalte" mellem Begivenheden selv og dens iscenesættelse, som Zizek beskriver, og som svarer til Mazzarellas ditto ("gap" mellem materialiteten og dens konceptuelle generalisering). Ved at dykke ned i medieringens genealogi bliver det muligt at trække de historiske og politiske relationer, som er trængt i baggrunden, frem i lyset igen. Dette vil medvirke til, at vi får en bedre forståelse for medieringens ideologi og politik som historisk betinget, og dermed ikke blot knyttet til en enkelt hændelse, og hvordan regime og opposition medierer den. 


\section{Medieringens genealogi}

"Perhaps most significantly, the politics of immediation has taken root because of Palestine's specific history..." (Allen 2009: 173)

Selvom Lori Allen i citatet ovenfor påpeger den palæstinensiske historie som det "måske mest vigtige" element $i$ at forklare "the politics of immediation", forfølger hun dog ikke denne pointe $i$ sin artikel. For at forstå det umedieredes politik i den syriske case er det dog afgørende at forstå den historiske dimension. Når det syriske regime udpeger al-Qaeda som ansvarlig for bombeangrebet, og når regime-sympatisører fremstiller Det Muslimske Broderskab som en farlig og voldelig opposition vises også implicit hvilke skræmmende alternativer, der kunne være til den nuværende samfundsorden. Hermed kommer det syriske regime til at stå som sikkerhedsgarant for sameksistens og fred mod en ekstremistisk islamisk fare. Dette legitimerende narrativ for regimets eksistensberettigelse kan anskues som konsekvens af fire årtiers skiftende relationer med det sunnimuslimske milj $\varnothing^{10}$. Disse kan deles op i tre perioder - en repressiv periode i 1970-1980erne, en liberaliserende i 1990erne og en repressiv fra 2008 og frem mod opstanden. Ved at se lidt nærmere på relationerne mellem det sunni-muslimske miljø og det syriske regime tegner sig konturerne af en bestemt, officiel form for islam som dels virker legitimerende i forhold til regimets egen eksistens og dels repressiv i forhold til konkurrerende udgaver af islam. Lad os se lidt nærmere på de tre nævnte perioder:

Fortællingen om det ba' thistiske styre under Asad (først den ældre og siden den yngre ${ }^{11}$ ) som garant for sameksistens og sikkerhed mod en islamistisk trussel kan spores tilbage - mindst - til det seneste oprør i landet, som begyndte i slutningen af 1970erne og fik et brat ophør med massakren i Hama i $1982^{12}$. Under dette oprør, hvor Det Muslimske Broderskab spillede en afgørende rolle, var retorikken generelt helt anderledes end i det nuværende oprør, som Jakob Skovgaard-Petersen også fremhæver i sin artikel om al-Buti i dette særnummer. Retorikken vendte sig bl.a. fjendtligt mod alawitter og påtalte nødvendigheden om en islamisk stat i Syrien.

I løbet af 1980erne var den sunni-muslimske scene under kraftig overvågning og pres fra regimets side. Eksempelvis blev de to brødre, Shaykh Osama og Sariya al-Rifa'i, sendt i eksil i SaudiArabien. Brødrene havde overtaget deres fars indflydelsesrige islamiske uddannelses- og velgørenhedsnetværk, det såkaldte Jama'at Zayd, som blev opbygget i 1950erne med opførsel af (c) Forfatteren og Tidsskrift for Islamforskning, ISSN 1901-9580, publiceret 1-03-2013 
skoler og moskeer i Damaskus særligt omkring Suq Bab al-Sirije ikke langt fra den gamle bydel. Efter faderens død i 1973 havde Zayd-netværket tiltrukket medlemmer af Det Muslimske Broderskab. Den efterfølgende opstand mod regimet med den brutale kulmination i Hama i 1982 medvirkede derfor til marginaliseringen af Zayd fra regimets side.

Der tegnede sig således i kølvandet på massakren i Hama en strategi fra Præsident Hafez al-Asad's side, hvor nogle religiøse ledere og deres netværk blev marginaliseret, mens andre - som eksempelvis den daværende og nu afdøde statsmufti Shaykh Ahmad al-Kuftaro og hans Abu Nourorganisation - blev favoriseret. Abu Nour (Mujammu' Shaykh Ahmad Kuftaru) var dengang, ligesom i dag, en Damaskus-baseret organisation (omend der er afdelinger i andre dele af Syrien) med moske, udannelse indenfor islamiske discipliner og arabisk sprog og en række velgørenhedsaktiviteter ${ }^{13}$. Nogle sunni-muslimske ledere blev altså favoriseret (dem som faldt i tråd med regimets egen islam-version og ikke blev anset som en trussel) mens andre blev marginaliseret (deres version af islam var potentielt i modsætning til regimet):

Abu Nour under Kuftaru promoverede en regime-venlig eller "officiel" version af islam (Bötcher 1998, 2004, Pinto 2003), som i tillæg til Ahmad Kuftaru's officielle position som statsmufti og måske også personligt gode forhold til Hafez al-Asad (Stenberg 2005) gav organisationen gode levebetingelser, hvor andre - herunder Zayd-bevægelsen - måtte gå under jorden.

Det syriske regime under Hafez al-Asad valgte at skifte kurs i 1990erne i, hvad man kan kalde en liberalisering af det sunni-muslimske miljø (Pierret kommende publikation 2013). Sariya og Osama al-Rifa'i vendte tilbage til landet og genetablerede deres aktiviteter i Zayd-bevægelsen. Ifølge Thomas Pierret og Kjetil Selvik var dette et strategisk træk fra regimets side for at udvide støttebasen udover de traditionelle allierede som fx Kuftaru og Sa'id Ramadan al-Buti (Pierret og Selvik 2009). Noget tyder på, at denne strategi ikke virkede optimalt - i hvert fald valgte Bashar alAsad at iværksætte en række administrative ændringer i 2008, som kan tolkes som et kursskifte:

I sommeren 2008 indledte den nye minister for Awqaf (religiøse stiftelser), som var blevet udnævnt af Bashar al-Asad i december 2007, en strategi som omfattede tre elementer; institutionel reform, repressive tiltag og skridt til at "rulle den islamiske trend tilbage" i det bredere syriske samfund.

I september samme år springer en voldsom bilbombe nær det shi'a-muslimske Sayyida Zeinab mausoleum, som hvert år tiltrækker tusinder af pilgrimme fra bl.a. Iran. 17 mennesker dør i hvad syriske medier kalder "det blodigste angreb i to årtier". Den syriske regering anholder en formodet (C) Forfatteren og Tidsskrift for Islamforskning, ISSN 1901-9580, publiceret 1-03-2013 
gerningsmand med tilknytning til den ekstremistiske gruppe Fatah al-Islam, som har base i Libanon (se mere om gruppen i Rougier 2007). Fra officiel syrisk side oplyses, at gerningsmanden var blevet inspireret af jihadi ideologi i al-Fath instituttet i centrum af Damaskus (ma'had al-fath) og skaffede sig finansielle midler til angrebet "under dække af velgørende aktiviteter" (Pierret kommende publikation 2013).

Måneden efter indkaldes en række prominente ledere af religiøse stiftelser, institutioner og velgørenhedsorganisationer til et møde i Awqaf Ministeriet. En af mine informanter - en ledende islamisk prædikant og intellektuel som jeg interviewede i efteråret 2010 var en af de indbudte. Mødedeltagerne blev informeret om en række administrative ændringer, som ville påvirke deres institutioner: officielle personer fra styret blev placeret i institutionernes bestyrelser og Awqaf Ministeriet tog kontrollen med institutternes indkomstmuligheder. Andre af mine informanter fortalte mig, at tidligere havde private institutter mulighed for selv at indsamle penge fx via moskeer eller via investeringer, således at deres $\varnothing$ konomiske grundlag blev sikret og lønninger til fx undervisere og andre medarbejdere kunne udbetales. Disse muligheder blev nu stærkt indskrænkede og udsat for gennemgribende kontrol. Derudover forsøgte det syriske styre også at kontrollere indholdet i religiøs undervisning ved at standardisere pensa i shari'a undervisning. Moskeer blev overvåget og alle fredagsprædikener registreret af en eller flere medlemmer af de syriske efterretningstjenester.

Ministeren for Awqaf, Muhammad al-Sayyid, annoncerede at disse administrative reformer blev iværksat for at "ende denne æra med anarki" hvor "hvert institut (dvs. religiøse institutter, red.) var en stat i staten”. De religiøse institutter skulle nu ifølge ministeren være afhængige af ministeriet set "fra et administrativt, videnskabeligt, udannelsesmæssigt og finansielt synspunkt" (Pierret kommende publikation 2013: 28). I november 2010 overværede jeg en fredagsbøn, hvor Osama alRifa'i var prædikant, i Masjid Abdul Karim al-Rifa'i tæt ved Kafr Suseh distriktet i det centrale Damaskus. Efter fredagsbønnen blev der samlet penge ind i opstillede montre, som blev administreret af Sammenslutningen for Velgørenhedsorganisationer i Damaskus (itihad aljama'iyat al-khayriyya) - en regime-drevet paraplyorganisation for velgørenhedsorganisationer. Dette var et tydeligt eksempel på, hvordan det syriske styre søgte at kontrollere indtægtskilderne fra en muslimsk menighed (Masjid Abdul Karim al-Rifa'i) og organisation (Zayd-bevægelsen).

Mine informanter i det sunni-muslimske miljø i Damaskus gav udtryk for denne skærpede kontrol under mit feltarbejde i efteråret 2010. De nævnte, at der var taget yderligere skridt som tiltag i (C) Forfatteren og Tidsskrift for Islamforskning, ISSN 1901-9580, publiceret 1-03-2013 
kampagnen for $\emptyset$ get kontrol fra styrets side. Eksempelvis blev det forbudt for klerikale ledere at sidde i bestyrelser for velgørenhedsorganisationer. Ydermere skulle velgørenhedsorganisationerne (eller "afdelingerne" om man vil) administrativt adskilles fra religiøse institutter. Det betød fx for Abu Nour, at deres velgørenhedsorganisation, al-Ansar, måtte adskilles fra organisationen og oprette en selvstændig administration med hvad dertil hørte af sikring af indtægter, drift, separat hjemmeside, osv. For mine informanter var dette udtryk for pres fra regimets side.

Udover de administrative reformer gennemførte det syriske regime også en række repressive nedslag i samfundet, hvilket udgjorde den anden del af strategien. Det mest kendte tiltag i denne del af strategien og som også fik noget omtale i vestlige medier var forbuddet mod at bære niqab (det muslimske klæde som dækker ansigt og hoved på nær øjnene) på universitetet. Derudover blev en række tildækkede skolelærere overført til andre dele af den syriske administration. Også en række mere kendte enkeltpersoner blev ramt af repressionen. Salah Kuftaru - søn af Ahmad Kuftaru blev fængslet og anklaget for korruption. Han blev dog senere løsladt og anklagerne imod ham frafaldt. Muhammad Habash - en anden kendt religiøs lærd - blev tvunget til at fratræde sine religiøse poster. Andre sunni-muslimske lederskikkelser, som en af mine informanter, blev med jævne mellemrum tilbageholdt og afhørt af efterretningstjenesterne (mukhabarat).

Et lidt nærmere kig på relationerne mellem stat og det sunni-muslimske miljø viser således, at nogle toneangivende grupperinger blev favoriseret på bekostning af andre. Historisk set har der således været skiftende strategier fra det syriske regimes side, som ved at støtte nogle grupperinger også implicit støttede deres version af islam. Ved at marginalisere andre grupperinger medvirkede denne strategi også til en reducering af deres frihed til at udøve religiøse praksis, samfundsanskuelse, osv. Dette er med til at forklare, hvorfor nogle forskere har anskuet eksempelvis Abu Nour under Kuftaru som statsmufti, som en form for "officiel islam". Men efter Kuftarus død og styrets strategiændring i 2008 blev Abu Nour og de fleste andre sunni-muslimske organisationer sat under stigende pres gennem de nævnte administrative ændringer, fysisk og psykisk repression (fængslinger, psykologisk chikane osv.) og bredere samfundsorienterede tiltag (fx niqab-forbud).

Strategierne til denne promovering af bestemte udgaver af islam har været skiftevis liberaliserende (som perioden i 1990erne) og repressive (som perioden i 1970erne-1980erne og slutningen af 2000tallet frem mod den nuværende krise). I alle perioderne er det den immanente, logiske konsekvens af regimets strategi at fremstille et billede af den syriske stat som garant for sikkerhed og sameksistens mellem forskelligartede etniske og religiøse grupper (minoriteterne - de kristne, (C) Forfatteren og Tidsskrift for Islamforskning, ISSN 1901-9580, publiceret 1-03-2013 
allawitterne, druserne - og den sunni-muslimske majoritet kunne således praktisere deres tro side om side). Perioden i 1970erne og '80erne, hvor den syriske stat var "truet" af en islamistisk fare (Broderskabet) som blev slået tilbage er helt central for regimets egen selvopfattelse, selvlegitimering og medieringsmekanismer. Der er således en historisk rød tråd i regimets narrativ om sig selv - fra at have slået oprøret ned i 1970erne, til "det blodigste angreb i to årtier" i 2008 og til at pege på al-Qaeda og Broderskabet som ansvarlige for bomben i Kafer Suseh i 2011. Den "islamistiske trussel" bliver gang på gang slået tilbage af garanten for sikkerhed og sameksistens nemlig den syriske stat. Når regimet udpeger al-Qaeda som ansvarlige er det ikke tilfældigt, men derimod en fortsættelse af det historiske narrativ om den syriske stat som nedkæmper af islamistiske trusler og ultimativ garant for sikkerhed. De historiske forudsætninger ekspliciteres ikke - og hermed findes den skjulte benægtelse af mediering på regimets side. Benægtelsen indfinder sig implicit i regimets ideologiske, usagte autoritetsstrategi - dvs. en strategi som på ideologiskhistorisk vis legitimerer regimet. På anti-regime aktivisternes side udfordrer "afsløringen" af Qas Nasrallah således en historisk meget robust fortælling fra regimets side om sig selv.

\section{"Vi har aldrig takfiri-studerende!"}

Gennemgangen ovenfor viser, hvordan det syriske regime historisk har forsøgt skiftevis at liberalisere, regulere, undertrykke og frem for alt kontrollere det toneangivende sunni-muslimske miljø. Medieringen af bombningerne i Kafer Suseh er således fortsættelsen af regimets ideologiske autoritetsstrategi. Denne strategi promoverede også en bestemt udgave af islam, som ikke var konfliktfyldt i forhold til regimet. Dette kom bogstaveligt til udtryk i ministeren for Awqafs udtalelser i forbindelse med de administrative reformer i 2008 og efter bomben ved Sayyida Zeinabs mausoleum. Her udtalte ministeren, at reformerne blev iværksat for at "rense islamisk tankegang for pletter af Wahhabisme og Takfirisme" (Pierret kommende publikation 2013: 28). Denne officielle udgave af islam var den logiske konsekvens af de administrative reformer, men endnu et vigtigt element kan tilføjes - nemlig vedligeholdelsen af autoritetsstrategien af muslimske aktørers måder at agere og tale på i det offentlige rum ${ }^{14}$. Det var således ikke blot påkrævet at administrative reformer blev implementeret, men muslimske aktører skulle også i det offentlige rum italesætte den officielle form for islam. En lignende italesættelse er tidligere blevet diskuteret som "politics of as if" af Lisa Wedeen (Wedeen 1999) ${ }^{15}$. Den normative vedligeholdelse eller italesættelse kom til udtryk under mit feltarbejde i 2010, hvor jeg bl.a. frekventerede en stor

(c) Forfatteren og Tidsskrift for Islamforskning, ISSN 1901-9580, publiceret 1-03-2013 
uddannelsesorganisation, som er opkaldt efter en kendt syrisk islamisk lærd ('alim), som levede og underviste før, under og efter det franske mandat i Syrien:

"Organisationen for Den Største Hadith Lærd, Sheikh Badr al-Din al-Hasani” (jama'iyat almuhadith al-akbar al-Sheikh Badr al-Din al-Hasani) er det officielle navn for udannelsesorganisationen som i 2010 udannede 1200 studerende i islamiske discipliner (hvoraf de 600 boede i bygningskomplekset, som ligger op ad kirkegården ved Bab al-Saghir i det centrale Damaskus). Organisationen bliver også omtalt som et "ma'had" - et institut for islamisk uddannelse. Ifølge det officielle informationsmateriale blev instituttet etableret allerede i 2000 efter præsidentiel ordre. I informationsmaterialet er målet med instituttet at uddanne fremtidige religiøse lærde og prædikanter og "at sprede eksemplarisk moral og kærlighed til fædrelandet" (nashara alfadila wa hub al-watan). 'Amar er en central administrator ved Badr al-Din instituttet. Under vores samtaler i efteråret 2010 var det bemærkelsesværdigt, at han flere gange var ivrig for at fremhæve at deres studerende var "ikke-takfiri". Det var aldrig noget jeg spurgte om og forekom altid på 'Amars initiativ - som fx på dette udklip af mine feltnoter:

"Vi tager aldrig takfiri studerende ind. Inden de bliver accepteret, laerer vi om deres baggrund generelt, om deres fars profession, og andre ting... Vi ser om de har takfiri eller terrorist-tanker. Vi valger aldrig dem med disse tanker. (...) Vi kender profeten virkeligt (haqiqa) og vi vil lare andre. (...) Unge mennesker i alderen 15-20 har mange tanker. Spфrgsmålet er, hvordan vi andrer deres tanker. (...) Det vigtigste er, at de ikke tanker forkert.” Jeg spørger ham om han mener, at instituttet er del af en social bevægelse. "Du kan godt sige vi er del af en social bevagelse (haraka ijtima'iyya), men en som er toet på staten.”

Således blev den officielle udgave af Islam, renset for "takfirisme og wahhabisme", som en konsekvens af de administrative reformer og repressive tiltag som blev iværksat i 2008, opretholdt gennem 'Amars tale og på hans eget initiativ ${ }^{16}$. I samtaler med en anden administrator spurgte jeg også ind til den historiske Badr al-Din al-Hasani, og hvorfor han lagde navn til instituttet. "Hans da'wa var for hele Syrien," svarede administratoren. Observationer i Badr al-Din instituttet, interviews med administratorer, det officielle informationsmateriale, en biografi om al-Hasani ${ }^{17}$, som jeg fik udleveret på instituttet, samt mit øvrige feltarbejde indikerer, at det syriske regime søgte at promovere en officiel udgave af islam dels gennem "egne" læringsinstitutioner som Badr al-Din al-Hasani, og dels ved at kontrollere eksisterende sunni-muslimske samfundsorganisationer som fx Abu Nour og Jama'at Zayd. Kontrollen var finansiel, men også normativ - regimet søgte ikke blot (C) Forfatteren og Tidsskrift for Islamforskning, ISSN 1901-9580, publiceret 1-03-2013 
at kontrollere det finansielle grundlag for institutterne, men også indholdet af undervisning (standardisering af curricula er allerede nævnt som eksempel), personlige udtryksformer (niqabforbud) og der var tilmed en informant, som kunne navngive en person der sad fængslet i det berygtede Sednaya fængsel angiveligt blot fordi han ejede en bog af den hanbalitiske lærde Ibn Taymiyya (1263-1328). Bl.a. af disse grunde gav mange af mine informanter udtryk for en følelse af, at være under konstant pres fra regimets side.

\section{Det umedieredes politik}

Vi får muligvis aldrig at vide hvem der rent faktisk stod bag bomben i Kafer Suseh den 23. december. Dette ville kræve en uvildig undersøgelse og juridisk proces, som ikke synes mulig i en overskuelig fremtid i det borgerkrigsramte Syrien. Men netop fraværet af en retsproces åbner et tomrum, som søges fyldt ud af forskellige syriske aktører. Denne artikel har beskæftiget sig med tre forskellige typer af aktører, som var aktive i det skelsættende mediedøgn, hvor kampen om at virkeliggøre bombe-hændelsen udspillede sig - nemlig det syriske regime (via det statslige nyhedsbureau Sana), en syrisk regime sympatisør (via den falske Broderskabs-side ikhwan-sy.com) og syriske oppositionelle netaktivister (via adskillige sider på bl.a. Facebook og who-is.com).

Et typisk kig på nyhedsstrømmen i internationale eller nationale syriske medier den 23. december viste billeder af bombe-stedet og i varierende grader sårede og døde mennesker. Generelt har indslag i fx TV om horrible hændelser i Syrien relativ kort varighed og kan vise visuelt voldsomme billeder af døde eller lemlæstede kroppe, som chokerer seere - og som sikkert også drager dem til skærmen (Sontag 2003). Denne artikel søger at trænge bag medieringen af bomben den 23. december. Dette gøres ved at analysere det, som karakteriserer medieringens umiddelbarhed og virkelighed (Barthes 2004) - artiklen udforsker således det chokerende, dragende og horribles kontekst:

Ikke blot har sådanne billeder en historie, som hjælper os til at forstå baggrunden for deres fremstilling. Historien viser også, hvordan bomben den 23. december indgår i forskellige syriske aktørers politiske projekter eller "autoritetsstrategier" (Mazarella 2004, 2006), og viser hvordan forskellige typer af medier, nemlig internettet og tv, spiller sammen i promoveringen af disse projekter; 
Det syriske regime var meget hurtig til at udpege al-Qaeda som ansvarlige for bomben. Den umiddelbare respons er ikke overraskende, hvis man tager gennemgangen af den syriske historie ovenfor i betragtning. Det syriske regimes narrativ - forstået som det retoriske, medierende fors $\emptyset \mathrm{g}$ på virkeliggørelse - forbinder den nuværende opstand til det tidligere islamistiske oprør, hvor den syriske stat viste sig som den ultimative nedkæmper af oprør og garant for sikkerhed og sameksistens mellem de forskellige etniske og religiøse befolkningsgrupper i landet.

Men selvsamme narrativ fra det syriske regimes side har også en historie, hvor ikke blot administrativ, men også normativ regulering af det sunni-muslimske miljø med skiftende strategier marginaliserede mange muslimer, som var aktive i uddannelses- og velgørenhedsorganisationer, umiddelbart op til opstanden. Det er ikke denne artikels hensigt at skabe en kausal forbindelse mellem bomben i Kafer Suseh den 23. december og årtiers varierende repression af det sunnimuslimske miljø i Damaskus. Men det kan sandsynliggøres, at det syriske regimes administrative og repressive tiltag også havde en normativ eller "symbolsk" dimension - dvs. en medfølgende promovering af en bestemt udgave af islam som del af regimets eget legitimerende narrativ om at være garant for fred og sameksistens.

Når syriske netaktivister, hvoraf nogle er direkte affilieret med Det Muslimske Broderskab, ansvarliggør regimet for bomben, rammer de i hjertet af regimets legitimerende narrativ. Hvis regimet vitterligt stod bag bomben, ville det være regimet og ikke islamister, der var Syriens fjende. Man kan således sige, at aktivisterne bruger regimets eget narrativ mod regimet selv ved hjælp af sociale medier (Facebook, mv.), værktøjer på internettet (who-is.com) og spreder dette modnarrativ via massemedier (gennem de korrigerende nyheder, som blev bragt i internationale, herunder danske medier).

Træder vi endnu et skridt tilbage analytisk set kan vi således også sandsynliggøre, at der i forbindelse med denne kamp om virkeliggørelse af bomben den 23. december også sættes spørgsmålstegn ved om det syriske regime er de legitime magthavere i Syrien. Og hermed sættes også spørgsmålstegn ved islams rolle i det fremtidige Syrien. Spørgsmålet er, hvorvidt der fortsat skal være en officielt accepteret version af islam eller om muslimer skal have selvbestemmelse over deres religiøse tro og praksis. Der foregår en kamp på et mere grundlæggende niveau - nemlig om at gen-opfinde den syriske stat, dens legitime repræsentanter og islams rolle heri. En mulig konsekvens kunne være, at Broderskabet går fra at være en udgrænset gruppering i det officielle Syrien til en legitim spiller på den kulturelle og politiske arena. For visse grupperinger i Syrien er 
den udsigt stærkt bekymrende - og det i en sådan grad, at en kristen aktivist med relationer direkte til magtfulde cirkler i regimet konstruerer en falsk hjemmeside for at de-legitimere Broderskabet som politisk aktør i Syrien. For både denne regime-sympatisør som for regimet selv fremstilles politisk inddragelse af islam i Syrien som et stærkt truende perspektiv.

Casen i denne artikel viser også et eksempel på netaktivisters kreative sensations-effekt. De mange kommentarer på de forskellige netsider giver udtryk for opbakningen til deres konklusioner. Afgørende er det imidlertid, hvordan "almindelige" syrere opfatter disse nyhedsstrømme. Nogle har fulgt aktivisternes "afsløring", mens andre blot har set nyhedsindslag fra statsligt, pan-arabisk eller internationalt TV. Desværre er såkaldte "audience studies" i Syrien fra et metodisk synspunkt meget vanskelig. Men i sidste instans må retorik, narrativer, medieringer og virkeliggørelsens tråde spores på en kritisk måde blandt syrere, som er vante mediebrugere - med mobiltelefoner, internet, fjernsyn og radio.

\section{Litteratur}

Allen, Lori A., 2009: 'Martyr bodies in the media: Human rights, aesthetics, and the politics of immediation in the Palestinian intifada', p. 161-180, American Ethnologist 36:1.

Barthes, Roland, 2004: 'Virkelighedseffekten', p. 147-161, i: Roland Barthes Forfatterens d $\phi d$ og andre essays, Denmark: Gyldendal.

Bötcher, Annabelle, 1998: Syrische Religionspolitik unter Asad, Arnold-Bergstraesser-Institut, Freiburg, Karlsruhe.

Bötcher, Annabelle, 2004: 'Official Islam, Transnational Islamic Networks, and Regional Politics': The Case of Syria, in: The Middle East and Palestine: Global Politics and Regional Conflict, ed. Dietrich Jung, Palgrave Macmillan.

Chagas, Gisele Fonseca, 2011: 'Muslim Women and the work of $d a$ 'wa: the female branch of the tariqa Naqshbandiyya-Kuftariyya in Damascus, Syria', p. 207-218, Middle East Critique 20:2.

de Vries, Hent, 2001: 'In Medias Res: Global Religion, Public Spheres, and the Task of Contemporary Religious Studies', p. 3-43, i Hent de Vries og Samuel Weber: Religion and Media, California: Stanford University Press.

Donker, Teije Hidde, 2010: 'Enduring Ambiguity: Sunni Community-Syrian Regime Dynamics', in: Mediterranean Politics, p. 435-452, vol 15, no 3. 
Eisenlohr, 2011: 'The anthropology of media and the question of ethnic and religious pluralism', $\mathrm{p}$. 40-55, Social Anthropology 19.

Engelke, Matthew, 2011: 'Response to Charles Hirschkind. Religion and transduction', 90-102, Social Anthropology 19.

Hirschkind, Charles, 2011: 'Media, mediation, religion', p. 90-102, Social Anthropology 19.

Hofheinz, Albrecht, 2011: 'Nextopia? Beyond Revolution 2.0', in: International Journal of Communication, Feature p. 1417-1434, vol 5.

Mazarella, William, 2004: 'Culture, Globalization, Mediation', p. 345-367, Annual Review of Anthropology 33.

Mazarella, William, 2006: 'Internet X-ray: e-governance, transparency, and the politics of immediation in India', p. 473-505, Public Culture 18.

Meyer, Birgit, 2010: 'Aesthetics of Persuasion: Global Christianity and Pentecostalism's Sensational Forms', p. 741-763, South Atlantic Quarterly 109: 4.

Meyer, Birgit, 2011: 'Mediation and immediacy: sensational forms, semiotic ideologies and the question of the medium', p. 23-39, Social Anthropology 19.

Pinto, Paulo, 2003: 'Dangerous Liasons: Sufism and the State in Syria', In: Crossing Boundaries: From Syria to Slovakia, ed. S. Jakelic and J. Varsoke, Vienna: IWM Junior Visiting Fellows' Conference, vol. 14

Pierret, Thomas, 2011a: 'Syrie: L’islam dans la revolution', in: Politique Étrangère, p. 879-891, vol. 4.

Pierret, Thomas, 2011b: Baas et Islam en Syrie: La dynastie Assad face aux Oulémas, Presses Universitaires de France - PUF.

Pierret, Thomas, 2013: "The State Management of Religion in Syria: The "End" of "Indirect Rule"?', upubliceret manuskript - udkommer i: Middle East Authoritarianisms: Governance, Contestation, and Regime Resilience in Syria and Iran, ed. Steven Heidemann og Reinoud Leenders, p. 83-107, Stanford University Press.

Pierret, Thomas og Selvik, Kjetil, 2009: Limits of "Authoritarian Upgrading in Syria": Private Welfare, Islamic Charities, and the Rise of the Zayd Movement, in: International Journal of Middle East Studies, p. 595-614, vol 41, no 4.

Rougier, Bernard, 2007: Everyday Jihad. The Rise of Militant Islam among Palestinians in Lebanon, Cambridge: Havard University Press.

Sontag, Susan, 1977: On photography, England: Penguin Books.

Sontag, Susan, 2003: At betragte andres lidelser, København: Tiderne Skifter. (C) Forfatteren og Tidsskrift for Islamforskning, ISSN 1901-9580, publiceret 1-03-2013 
Zizek,Slavoj, 2008: Ideologiens sublime objekt, Anden udgave, København: Hans Reitzels Forlag.

Wedeen, Lisa, 1999: Ambiguities of Domination: Politics, Rhetoric and Symbols in Contemporary

Syria, University of Chicago Press.

\section{Forfatterpræsentation}

Thomas Vladimir Brønd er Ph.D-stipendiat ved Institut for Samfund og Globalisering ved Roskilde Universitet, hvor han er tilknyttet forskningsgruppen "Secular Ideology in the Middle East" (SIME). Han er tidligere forskningsassistent ved Center for den Nye Islamiske Offentlighed (CNIO) ved Københavns Universitet og tidligere ekstern lektor ved Forsvarsakademiet. I sin Ph.D undersøger han hvordan sunni muslimske grupperinger i den syriske opstand forholder sig til sekulære dynamikker, og hvordan de diskuterer fremtidens syriske stat og islams rolle heri.

\footnotetext{
${ }^{1}$ Se fx artikel i Washington Post den 23. december: http://www.washingtonpost.com/world/middle east/explosionsrock-damascus-state-media-reports-many-dead/2011/12/23/gIQAHsWFDP story.html

"Med "narrativ" mener jeg den overordnede fortælling eller den fortællende "røde tråd", som forbinder subjektive bestræbelser på at fremstille umiddelbart forskellige begivenheder, til en samlet "fortælling", som virker logisk og sammenhængende.

${ }^{3}$ http://blogs.mediapart.fr/blog/thomas-pierret/271211/les-attentats-de-damas-revendiques-par-un-proche-dugrand-mufti. Thomas Pierret er "lecturer in contemporary Islam" med speciale i Islam i Syrien.

${ }^{4}$ Whois.com er en side, hvor man kan registrere og købe domæner, men man kan også spore allerede registrerede domæner via "whois lookup".

${ }^{5}$ Nogle steder endda med billede af Qas Nasrallah (se fx. http://sport4ever.maktoob.com/t801842-948/)

${ }^{6}$ Fx http://ar-ar.facebook.com/DaraaCoordination/posts/196412160452868 (med 11.025 "likes"), http://arar.facebook.com/HonestSyria/posts/196441723784013 (med 19.426 "likes") og http://www.facebook.com/Syrian.Revolution/posts/334974969847205. Sidstnævnte side er en af de mest centrale aktivistsider i den syriske opstand, ikke mindst i begyndelsen af opstanden, og har hele 436.839 "likes". Antallet af "likes" og sider, der behandler spørgsmålet, vidner om at mange har orienteret sig om "afsløringen" af Emile Qas Nasrallah. Administratoren af denne side er affilieret med Det Muslimske Broderskab.

${ }^{7}$ Ved æstetik forstås ikke kunst eller studiet af det smukke, men en bredere forståelse, som ifølge Lori Allen er tættere på det græske "aisthesis" - "sanseoplevelse", dvs.: "...the immediacy of reaction to images, unaffected by rules or selfinterest, something that emerged out of shared sensibilities, not a product of rational calculations.". (Allen 2009: 171) ${ }^{8}$ http://globalvoicesonline.org/2011/12/24/syria-regime-affiliates-try-to-frame-muslim-brotherhood-for-damascuscar-bombs/

${ }_{9}^{9}$ Denne konklusion er klar i mange af de kommentarer, som efterfølger afsløringen på Facebook-siderne.

${ }^{10}$ Valget af netop denne periodisering er sket af to grunde; dels fordi netop udviklinger i de seneste årtier stadig er præsent i syrernes kollektive hukommelse og fordi denne udvikling er den mest centrale for artiklens pointer, dels fordi denne artikels begrænsede omfang ikke tillader inddragelse af ellers relevante historiske perioder, ikke mindst den turbulente politiske periode efter uafhængigheden fra fransk kolonial administration og henholdsvis den franske og osmanniske periode i Syrien.

${ }^{11}$ Hermed ikke antydet, at der ikke er forskelle i det politiske regime som henholdsvis Hafez og Bashar al-Asad har stået i spidsen for (for en overskuelig gennemgang af ændringer Bashar foretog da han kom til magten, se bl.a. Volker Perthes: Syria Under Bashar al-Asad: Modernization and the Limits of Change, Adelphi Papers, vol 44, issue 36).
} 
${ }^{12}$ Bat'hismen som politisk ideologi går selvsagt længere tilbage, ligesom de sociale og politiske forudsætninger for Hafez al-Assads vej til magten har en længere historie. Det er dog udenfor artiklens omfang at behandle disse forhold indgående.

${ }^{13}$ Transnationalt har bevægelsen også nogen indflydelse (Chagas 2011), og internt i Syrien anslog en af mine egne informanter at bevægelsen havde omkring 250.000 sympatisører.

${ }^{14}$ Hermed skal det ikke forstås at den officielle udgave af islam havde en særlig endegyldig opskrift. Andres feltstudier viser derimod hvordan deres informanter i det muslimske miljø til tider havde vanskeligt ved at identificere "de røde linjer", men derimod fandt dem i deres praktiske relationer til regimet (se fx Donker 2010). Mine egne observationer kan således være med til at indikere, hvordan den officielle islam blev med-skabt og opretholdt i det offentlige rum af mine informanter.

${ }^{15}$ Forskningen er kommet et stykke vej siden Wedeens meget centrale værk Ambiguities of Domination: Politics, Rhetoric, and Symbols in Contemporary Syria, men det ligger udenfor denne artikel at diskutere dette mere indgående.

${ }^{16}$ Ordet "takfir" kommer fra verbet "kaffara", som betyder "at erklære (nogen) for kafir (ikke-troende)", og blev i islamisk sammenhæng først brugt om den gruppe af Mekkas indbyggere, som afviste Profeten Muhammad (se Encyclopeadia of Islam, Brill, Second Edition). Begrebet har en lang historie, men har fundet en vigtig plads i moderne, populær, arabisk sprogbrug, hvor det i stigende grad bliver associeret med ekstremisme og terrorisme. En der er "takfiri" i den populære forståelse er en ekstremistisk, ofte salafistisk, terrorist som muligvis bruger vold til at bekæmpe andre muslimer, som han opfatter som kafir, og til at håndhæve sin ensidige fortolkning af religion. Det er derfor ikke overraskende, at flertallet af muslimer vender sig imod ideen om denne terroristiske, voldelige takfiri. Og derfor er det også påfaldende at 'Amar tager initiativ til denne udtalelse. Et andet vigtigt element i citatet er, at han fremhæver, at instituttet er del af en social bevægelse "tæt på staten". Disse to elementer i hans tale sammenlignet med den historiske gennemgang fordrer den tolkning, at 'Amar italesætter den officielle islam, og 'følger statens forskrifter'. Den officielle islam er retorisk universel, fredelig og sameksisterende, men virker i praksis repressiv i forskellige historiske perioder i Syrien.

${ }^{17}$ Mazin al-Mubarak 2007: al-ulama' wa maslaha al-ijtimaiyya: al-muhadith al-akbar, shayk badr al-din al-hasani, dar albasha'ir, dimasq. I min specialeafhandling har jeg argumenteret for, at regimet indgår i kampen om at gen-opfinde arven efter Badr al-Din al-Hasani, som var en historisk interessant figur. Al-Hasani var kendt for at transcendere forskelle mellem de muslimske madhahib (skoler eller retninger). Han brugte bl.a. også "sekulære" videnskaber, talte den kristne minoritets sag og spillede en vis rolle i "revolutionen" mod franskmændene. 